\title{
SISTEM PENDINGINAN AIR UNTUK PANEL SURYA DENGAN METODE FUZZY LOGIC
}

\author{
Maruto Swatara Loegimin ${ }^{1}$ Bamabang Sumantri ${ }^{2}$ Mochamad Ari Bagus Nugroho $^{3}$ Hasnira $^{4}$ \\ Novie Ayub Windarko ${ }^{4}$ \\ Politeknik Elektronika Negeri Surabaya \\ Jl. Raya ITS, Keputih Sukolilo, Surabaya, 60111 \\ E-mail: marutoswatara04@gmail.com, bambang@pens.ac.id, aribagusnugroho@gmail.com, \\ rhara@polibatam.ac.id, ayub@pens.ac.id
}

\begin{abstract}
Abstrak
Cahaya matahari merupakan salah satu bentuk energi dari sumber daya alam. Sumber daya alam matahari ini sudah banyak digunakan untuk memasok daya listrik di satelit komunikasi melalui sel surya. Sel surya ini dapat menghasilkan energi listrik dalam jumlah yang tidak terbatas langsung diambil dari matahari. Panel surya sendiri memiliki suhu maksimum badan yang mana mempengaruhi hasil panel surya. Panel sel surya mengalami penurunan kemampuan dalam menghasilkan listrik bila terlalu panas atau melawati batas efektifitas. Oleh sebab itu, maka dikembangkan sistem cooling tower dengan metode fuzzy Logic melalui penelitian ini dengan tujuan untuk memaksimalkan efisiensi panel solar cell dalam menghasilkan listrik dan menganalisis sistem Panel Surya (Photovoltaic). Data yang dianalisis adalah: 1) Metode pendinginan panel surya menggunakan sistem cooling tower dengan metode fuzzy logic, 2) Efisiensi Panel Sel Surya dalam menghasilkan listrik , 3) Daya listrik yang dihasilkan oleh Panel sel surya.

Hasil dari penelitian ini menjelaskan bahwa penggunaan fuzzy logic dapat mengatur kecepatan air untuk pendinginan pada panel sehingga dapat dikatakan bahwa sistem pendingin untuk panel surya cocok digunakan di daerah tropis, karena sinar matahari sangat berlimpah dan terlebih lagi di area jalur khatulistiwa.
\end{abstract}

Kata Kunci: Panel Surya (Photovoltaic), Sistem Cooling Tower, Fuzzy Logic.

\begin{abstract}
Sun light is one form of energy from natural resources. These solar natural resources have been widely used to supply electrical power in communication satellites through solar cells. This solar cell can produce unlimited amounts of electrical energy directly taken from the sun. The solar panel itself has the maximum body temperature which influences the output of the solar panel. Solar cell panels have a decreased ability to generate electricity if it overheats or goes through the limits of effectiveness. Therefore, a cooling tower system is developed using the Fuzzy Logic method through this study with the aim of maximizing the efficiency of solar cell panels in generating electricity and analyzing Solar Panel systems(Photovoltaic). The data analyzed are: 1) The method of cooling solar panels using the cooling tower system with fuzzy logic methods, 2) Efficiency of Solar Cell Panels in generating electricity, 3) Electric power produced by solar cell panels.

The results of this study explain that the use of fuzzy logic can regulate the speed of water for cooling on panels so that it can be said that the cooling system for solar panels is suitable for use in the tropics, because sunlight is very abundant and is in the equatorial area.
\end{abstract}

Keyword: Photovoltaic, Cooling Tower system, Fuzzy Logic.

\section{PENDAHULUAN}

Sebuah panel surya terbuat dari banyak sel surya. Sel tersambung secara elektrik untuk memberikan arus dan tegangan tertentu. Namun, Panel surya sendiri memiliki suhu maksimum body yang mana berpengaruh pada keluaran panel surya. Panel sel surya mengalami penurunan kemampuan dalam menghasilkan listrik bila terlalu panas atau melawati batas efektifitas. Oleh sebab itu, diperlukan system pendingin untuk mendinginkan atau menurunkan suhu pada panel sel surya, agar dapat menghasilkan aliran listrik secara efektif dan efisien.

Jika melihat pada proses pendinginan solar cell yang dilakukan dengan tujuan untuk menjaga suplai listrik dari panel solar cell tetap baik dan stabil pada suhu $25^{\circ} \mathrm{C}-35^{\circ} \mathrm{C}$ karena pada suhu tersebut panel solar dapat menghasilkan daya terbaik. Pada penelitian ini digunakan system 
cooling tower untuk menjaga suhu dan daya agar tetap konstan.

Microcontroller diperlukan untuk dapat mengontrol sistem secara otomatis dengan menggunakan fuzzy logic. Digunakan fuzzy logic karena dapat mengontrol alat dan dapat menentukan dan menjaga daya maupun suhu pada panel agar tetap stabil. Dengan metode ini secara langung dapat mempertahankan panel surya agar dapat menghasilkan listrik.

Berdasarkan penelitian Adhi Warsito[1] Saat penelitian ini akan dibuat pendingin panel surya dengan menggunakan heatsink fan. Didapatkan suhu rata-rata pada badan panel surya di kampus teknik elektro, tembalang pada pukul 9 pagi hingga 3 sore adalah $50.14^{\circ} \mathrm{C}$ dan keluaran rata-rata dari panel tersebut adalah 18.80 Volt. Sedangkan pada suhu rata-rata panel surya dengan menggunakan heatsink adalah $36^{\circ} \mathrm{C}$ dan keluaaran rata-rata penel tersebut adalah 19.11 Volt. Daya sendiri di pengaruhi oleh tegangan dan arus. Penurunan ratarata suhu panel surya dengan pendingin adalah $28,20 \%$ dan peningkatan efisiensi panel surya berubah dari $12,1 \%$ menjadi $13,74 \%$ karena menggunakan pendingin.

Amit Sahay[2] sistem pendingin panel di uji dengan menggunakan teknik "Smoke Flow Visualization" dari penelitian di temukan adanya peningktan efisiensi konversi karena pendinginan panel PV. System pendingin di pasang dan jika terintegrasi dengan desain panel solar PV maka pendinginan yang lebih efektif di harapkan dan karenanya efisiensi konversi akan lebih baik. Hasil pengamatan bahwa F- rasio pada kolom 38.85 lebih dari table F-rasio meningkat 5\% secara signifikan. Oleh karena itu efek pendinginandi temukan signifikan. Selanjutnya bahwa F-rasio pada baris 39.92 lebih dari table F-rasio pada tingkat signifikan $5 \%$ oleh karena itu pengaruh suhu panel pada efisiensi juga signifikan.

Chow T[3] Dalam kolektor PV / T, sel-sel fotovoltaik adalah bagian integral dari permukaan penyerap. Kolektor ini dikenal sebagai hybrid kolektor karena kemampuan bawaan mereka untuk menghasilkan listrik dan panas secara bersamaan. Prinsip kerja kolektor ini mirip dengan kolektor surya plat datar, kecuali bagian dari Insiden radiasi matahari diubah menjadi listrik. Jika panas cairan transfer (udara) mengalir melalui bagian aliran yang terpasang dengan permukaan penyerap, kolektor dikategorikan sebagai fotovoltaik-termal kolektor udara atau pemanas udara PV / T

Gabriel Colt[4] dalam tulisan ini, efek pendinginan panel PV dengan menambahkan penukar panas air dan dianalisis dengan simulasi numerik dan juga secara ekperimental. Dengan pendinginan air aktif, suhu turun secara signifikan kira-kira $32 \%$ (dari $50^{\circ} \mathrm{C}$ hingga $34^{\circ} \mathrm{C}$ ) yang mengarah ke peningkatan efisiensi panel PV sbesar $57 \%$ dari (7W menjadi $11 \mathrm{~W}$ ). Dengan mempelajari hasil pengukuran dan penelitian yang di tunjukan dapat ditarik kesimpulan sebagai berikut, laju aliran air tergantung pada suhunya dapat di control secara otomatis dengan menggunakan PLC.

Cui yong[5] Pendinginan matahari adalah alternatif yang menjanjikan dan bersih yang memiliki keunggulan berada dalam fase dengan permintaan pendinginan bangunan.

Gur Mittelman[7] merancang pendinginan dengan sistem berkonsentrasi photovoltaic/thermal (CPVT). Mereka mempersentasikan pendekatan panas dan daya gabuangan yang menggunakan teknologi CPVT kinerja tinggi untuk menghasilkan listrik dan energi termal pada suhu rendah atau medium.

Haitham M. Bahaidarah[8] menggunakan Vtrough sistem PV terintegrasi untuk menyelidiki efek pendinginan aktif pada kinerja optik, termal dan listrik. Perbandingan dibuat antara panel PV datar dan sistem V-trough PV. Ditemukan bahwa dengan menerapkan pendinginan daya panel PV sederhana meningkat sebesar $22,8 \%$ dan untuk palung V sebesar 31,5\%. Beberapa peneliti lain.

I.K. Karathanassis[9] secara eksperimental mempelajari parabola melalui sistem CPV / $\mathrm{T}$ dengan tiga konfigurasi penerima, menggabungkan sel PV yang berbeda dan desain bagian pendingin. Hasil mereka menunjukkan bahwa sel PV lebar mencapai efisiensi listrik yang lebih tinggi, dan heat sink dengan microchannels dengan lebar bervariasi secara bertahap menjanjikan karena daya pompa yang jauh lebih rendah kebutuhan.

J. P. Holman[10] Perpindahan panas maksimum per tetes yang terjadi pada permukaan panas (qmax) diamati sebagai fungsi dari sifat fluida dan komponen normal ud kecepatan dampak untuk superheat sekitar $165^{\circ} \mathrm{C}$ untuk air, aseton, alkohol, dan beberapa freon. Sebanyak $50 \%$ dari massa tetesan ditemukan menguap selama interval waktu singkat yang terkait dengan dampak dan memantul.

Khwe, K. H.[12] Suhu lingkungan juga berkontribusi terhadap perubahan suhu dalam panel surya. Karena kenaikan suhu, daya listrik yang dihasilkan oleh panel surya berkurang.

Kuswandi, S[13] Pada tahap Desain, kontroler logika fuzzy dirancang dan diterapkan pada sistem. Secara umum, kontroler logika fuzzy yang digunakan terdiri dari fuzzifikasi, inferensi, dan defuzzifikasi. Pengontrol logika fuzzy memiliki dua input: error dan delta error (derror), dan satu output: sinyal kontrol.

Matias[14] Dalam pendinginan panel fotovoltaik dengan aplikasi air pada permukaan depan, perpindahan panas dari permukaan panel ke air akan terjadi. Air akan menyerap panas dari panel fotovoltaik dengan konduksi panas, menyebabkan peningkatan level daya dan tegangan, dan meningkatkan efisiensi panel.

Mingke $\mathrm{Hu}[15]$ Berdasarkan hukum kedua termodinamika, fenomena pendinginan sub- 
ambient dan / atau energi pendingin bernilai ditemukan. Dengan demikian, dua solusi untuk pendinginan radiatif sub-ambien diterapkan untuk mengurangi kehilangan daya pendinginan intrinsik. Pertama, radiator dienkapsulasi dengan media khusus (seperti udara dan vakum) dengan konduktivitas termal yang rendah dan dikelilingi oleh kerangka isolasi.

Mulyono[16] alat pengganti suhu panas dengan menggunakan air dan udara sebagai kerja fluida adalah menara pendingin.

P G Nikhil[17 Jadi sistem PV surya bisa menjadi alternatif yang sangat logis untuk memanfaatkan energi matahari dengan memanfaatkan badan air yang dapat diperoleh dan membantu meningkatkan kelayakan ekonomi proyek surya. Energi dari fotovoltaik meskipun terbarukan sumber, mempertahankan efisiensi rendah kurang dari $15 \%$ umur panjang dalam penggunaannya.

Putra. R. S.[18] Dengan memperbaiki suhu air menggunakan menara pendingin dengan melepaskan suhu panas merupakan cara paling cara terbaik.

[19]

Roepandi, O[20] Menara pendingin mampu menurunkan suhu air dengan membuang panas. penggunaan teknologi dalam pengolahan air pendingin dapat disesuaikan dengan kebutuhan industri.

Syafaruddin[22] Pemanfaatan energi termal dengan cara sistem photovoltaicthermal telah diselidiki untuk meningkatkan kinerja efisiensi sistem fotovoltaik. Efisiensi listrik dinyatakan sangat rendah; namun, efisiensi keseluruhan dapat ditingkatkan dengan secara simultan memperoleh energi termal untuk sistem pemanas.

Yong Cui[24] menganalisis kinerja panel pemanas dan pendingin matahari dalam posisi vertikal. Dalam studi lebih lanjut, mereka menilai efek radiasi dan konveksi pada panel pendingin pada sudut kemiringan yang berbeda.

\section{Sistem Pendingin}

Sistem pendingin adalah suatu sistem yang bekerja menjaga atau menurunkan suhu pada kondisi ideal dengan cara memindahkan panas dari suatu bidang ke air atau udara. Perpindahan panas dasarnya merupakan perpindahan energi dari suatu tempat ke temapt yang lain dan ada perbedaan suhu di antara dua bagian benda. Panas akan pindah dari suhu tinggi ke suhu rendah [6].

Ada berbagai bentuk sistem pendingin mulai dari hembuasan udara, media perpindahan (heatsink), aliran air, dan pendingan dengan gabuang dari semua sistem tersebut.

\section{Karakteristik Photovoltaik}

Photovoltaic atau sel surya yang merupakan penggabungan antara bahan semikunduktor bertipe $\mathrm{p}$ dan $\mathrm{n}$ ( $\mathrm{p}-\mathrm{n}$ junction semiconductor) apabila terkana cahaya akan menghasilkan elektron. Elektron inilah yang merupakan arus listrik [4].

Berikut ini merupakan karakteristik sebuah panel surya:

a. Karakteristik daya, merupakan hasil perkalian antara kurva tegangan dan arus (V-I). karakteristik daya menunjukan seberapa besar daya yang dapat dihasilkan oleh panel surya, dalam perpotongan antara kurva arus dan tegangan akan menemukan sebuah titik yang disebut titik Maximum Power Point (MPP), gambar 1.

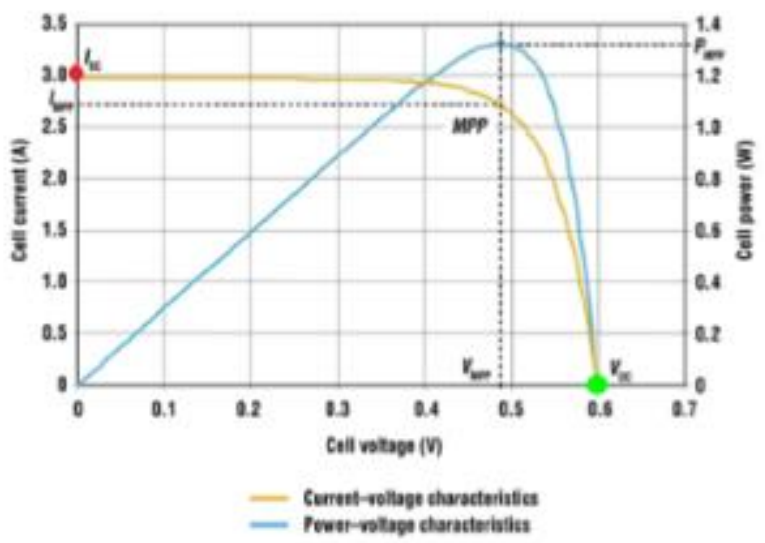

Gambar 1. Kurva MPP pada I-V.

b. Karakteristik I-V-Irradiasi, adalah kurva yang menunjukan hubungan antara arus dan tegangan pada irradisi yang terjadi pada panel surya, gambar 2 .

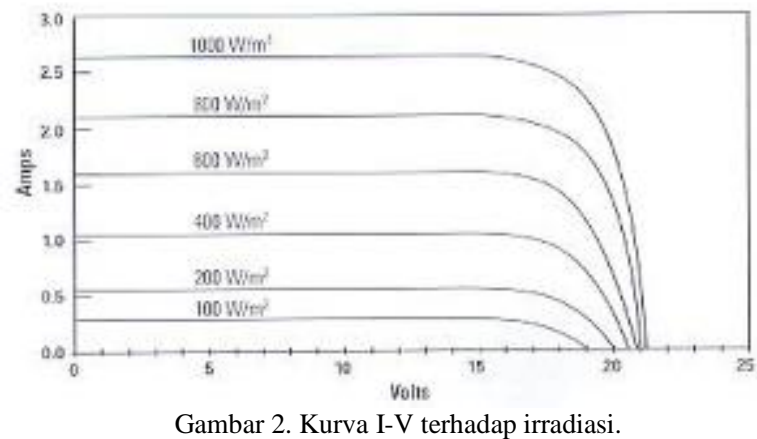

c. Karakteistik I-V-Temperatur, adalah kurva yang menunjukan hubungan antara arus dan tegangan di tempratur pada panel surya, gambar 3 . 


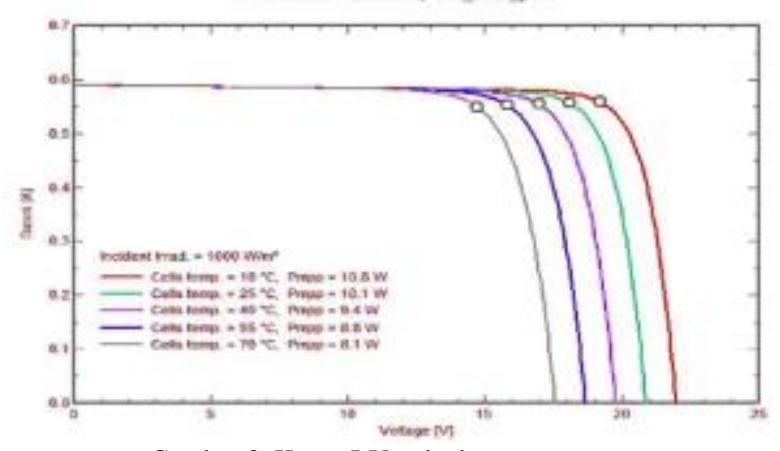

Gambar 3. Kurva I-V terhadap temperature.

Peningkatan peforma panel surya dengan menambakan reflector, dimana reflector ini berfungsi memantulkan cahaya matahari dan memfokuskannya pada panel surya.

Dengan menggunakan cara ini peningkatan untuk menghasilkan elektron lebih cepat dan temperatur panel surya naik dengan cepat juga menurunkan performa panel surya untuk menghasikan elektron. Untuk menjaga performa maka panel surya harus di inginkan dengan menjaga suhu panel surya pada kisaran $25^{\circ}$ sampai $35^{\circ}$ Celsius

Gabungan pendingin adalah sebuah gabungan antara pendinginan dengan hebusan udara, pemindah suhu (heatsink) dan pendingan dengan aliran air, dapat di lihat pada gambar 4. Sistem pendingin ini menggunakan pipa aluminium berbentuk kotak untuk mengalirkan air dan ditambahkan plat aluminium di atasnya untuk membuat pendinginannya merata gamabar 5. air yang keluar dari pipa akan di dinginkan dengan hembusan angin pada tower pendingin gambar 6 .

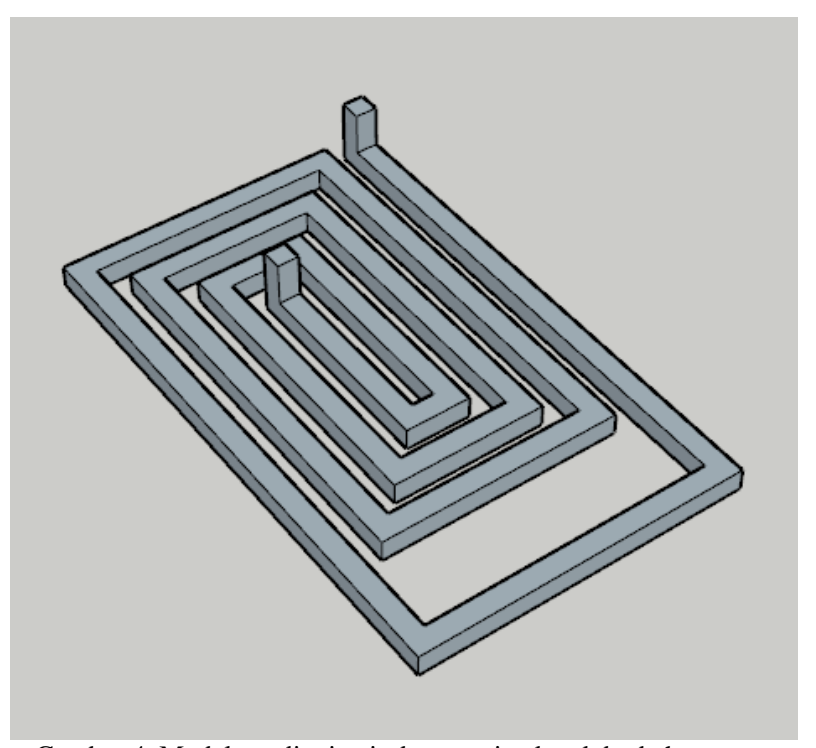

Gambar 4. Model pendingin air dengan pipa kotak berbahan aluminium.

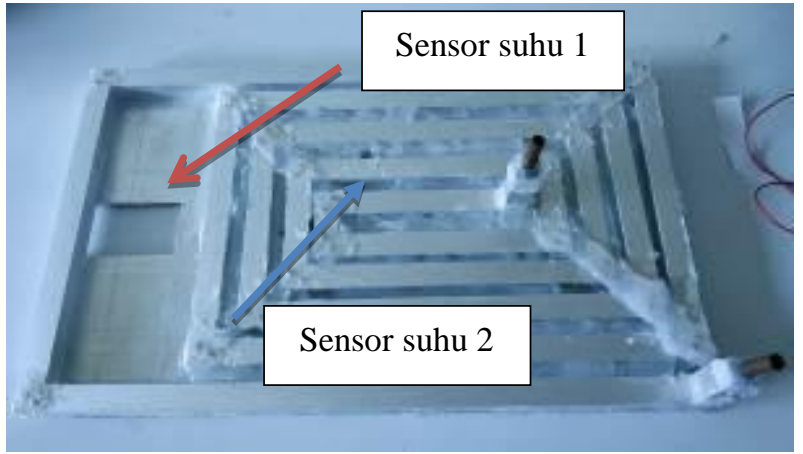

Gambar 5. Pipa dan plat alumunium yang digabungkan menjadi heatsink.

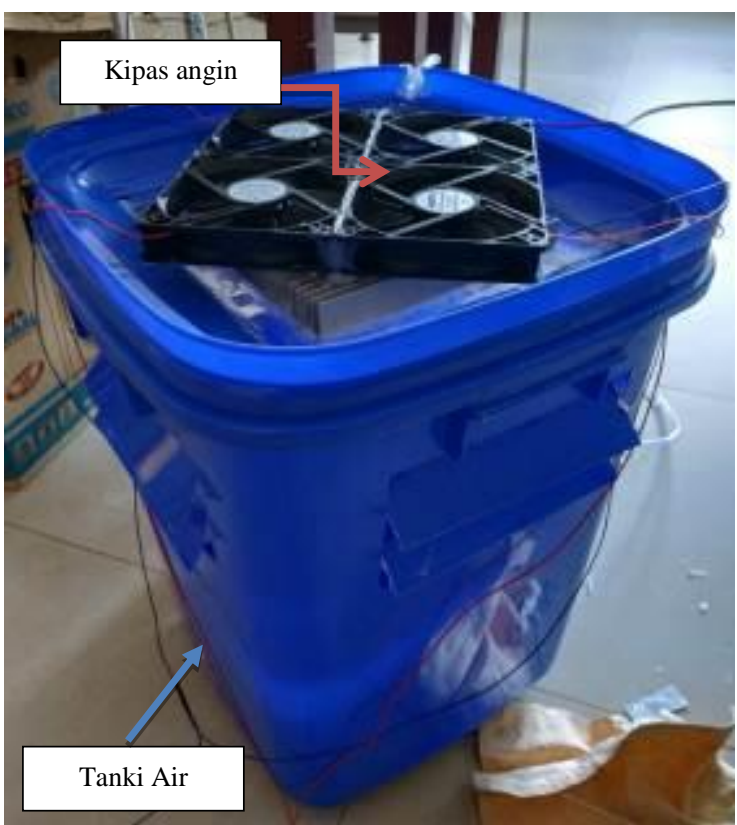

Gambar 6. Tanki penampung air cooling tower.

\section{METODE PENDINGINAN DAN KONTROL}

Metode yang digunakan dalam penelitian ini adalah metode kualitatif. Metode kualitatif merupakan prosedur penelitian yang menghasilkan data deskriptif berupa kata-kata tertulis atau lisan dari data perilaku yang dapat diamati.

\section{Konsep Perancangan Sistem Kendali dengan Microcontroller}

Sistem menggunakan stm32 merupakan sebuah sistem yang open source baik secara hardware maupun software. Perkembangan sistem software disesuaikan dengan perkembangan hardware-nya. 


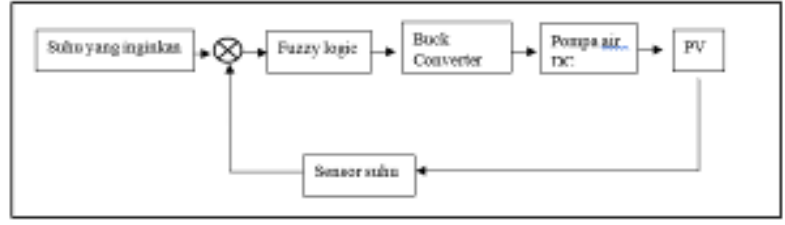

Gambar 7. Diagram alur sistem pendingin.

Dengan menggunakan sensor suhu DS18B20 yang di tempat di belakang panel surya, sensor ditempatkan pada dua tempat berbeda. Dimana setiap sensor mewakili posisi penempatan, ada yang langsung yang langsung pada panel surya untuk mengetahui suhu panel dan satunya lagi ditempatkan pada bagian pendingin panel surya yang akan menentukan kerja motor yang akan

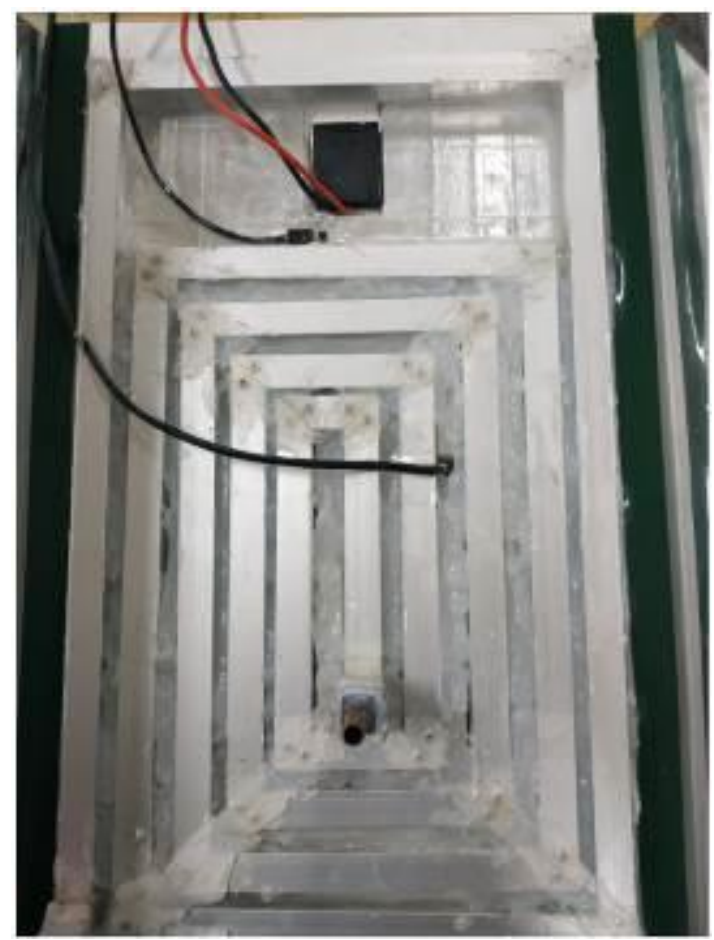

Gambar 8. Penempatan sensor temperature.

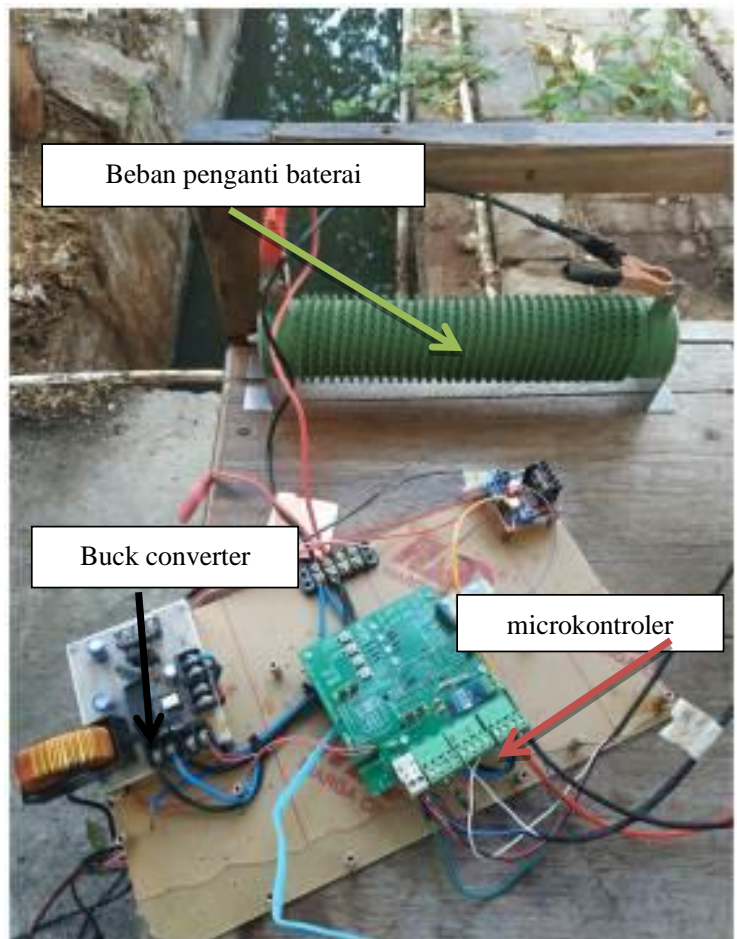

Gambar 9. Microkontroler, buck converter dan beban sebagai pengganti baterai.

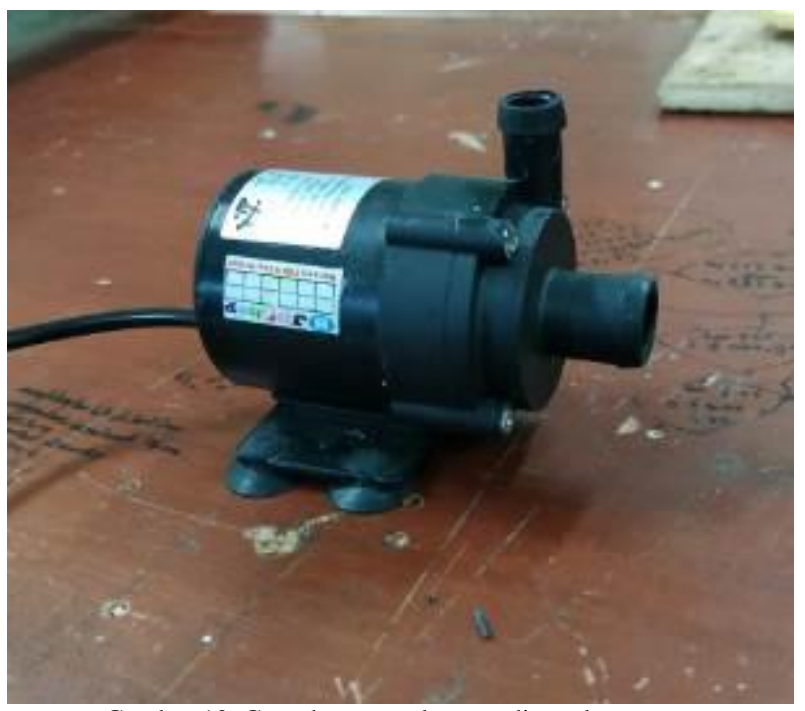

Gambar 10. Contoh pompa de yang digunakan.

mengalirkan air yang akan mendinginkan sebuah panel pendingin yang dibuat seperti pada gambar 4 dan gambar 5. 


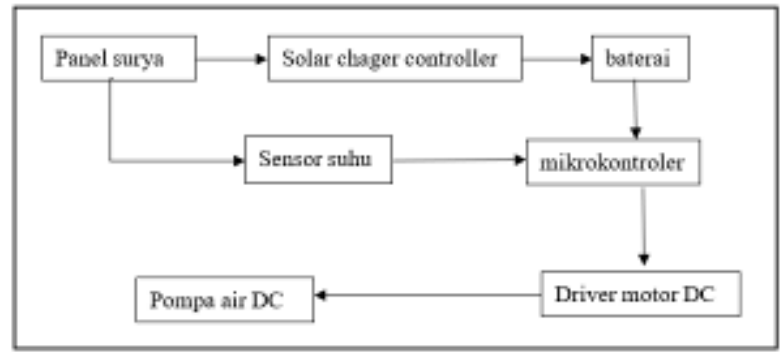

Gambar 11. Diagram blok sistem.

Dari gambar 8 menunjukan bagaimana pemrosesan untuk mendinginkan panel. Kecepatan air yang dialirkan akan meningkat apabila suhu panel menunjukan penikatan. Dengan suhu tertinggi $35^{\circ}$ Celsius, kecepatan motor di kontrol dengan menggunakan kotrol fuzzy sebagai pusat pengendali.

\section{Perancangan sistem Fuzzy Logic Control}

Fuzzy logic control mempuyai empat bagian untuk membuat struktur dasar dalam kendali fuzzy yaitu: fuzzifikasi, knowledge base, inferensi dan defuzzifikasi.

\section{Fuzzifikasi}

Untuk sistem pengendalian aliran air sebagai pendingin pada panel surya menggunakan satu inputan yang akan di fuzzyfikasikan ke dalam himpunan dan fungsi keanggotaan fuzzy. Dengan inputan yang ada dari sensor suhu yang terdapat pada panel surya. Dimasukan nilai linguistic sebanyak lima buah untuk sensor suhu panel surya yaitu Dingin (D), Sejuk (S), Normal (N), Hangat (H) dan Panas (P). nilai karakter linguistic bisa lihat pada table 1

Tabel 1. nilai input pada fuzzy logic

\begin{tabular}{|c|c|}
\hline Tipe Suhu & $\begin{array}{c}\text { Nilai suhu yang } \\
\text { ditentukan }\left({ }^{\circ} \mathrm{C}\right)\end{array}$ \\
\hline Dingin & $15-27.5$ \\
\hline Sejuk & $22.5-32.5$ \\
\hline Normal & $27.5-37.5$ \\
\hline Hangat & $32.5-42.5$ \\
\hline Panas & $37.5-50$ \\
\hline
\end{tabular}

Penentuan Dasar

Untuk mengontrol pompa air sebagai bagian dari pendingin panel surya, dapat diggunakan beberapa rule yang akan menjadi pengendali suhu pada panel surya. Dimana pemilihan rule merupakan penentuan nilai untuk mengontrol pompa air sebagai pendingin. Semakin banyak rule yang di buat, akan semakin kecil kesalahan yang terjadi pada alat.

Rule merupakan pengelompokan matrik yang dikenal dengan Fuzzy Associative Memory atau disingkat dengan FAM.

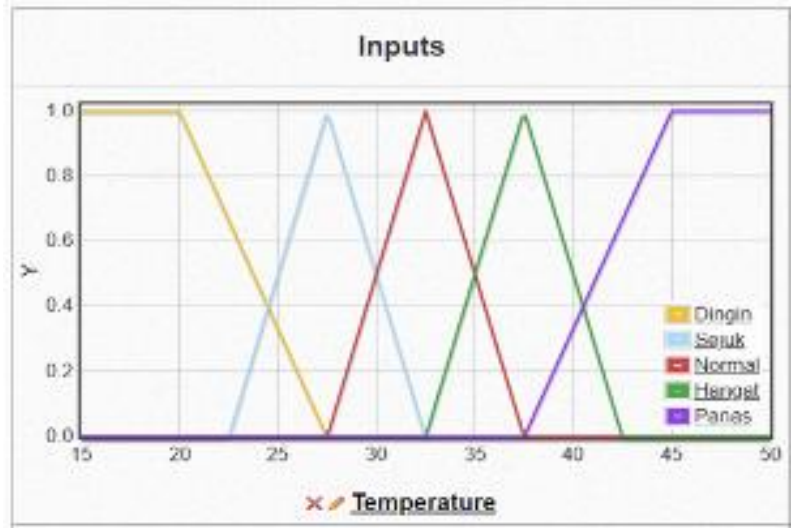

Gambar 12. Input fuzzy logic untuk pendinginan panel surya.

Inferensi

Merupakan proses matrik FAM dalam menentukan nilai maksimal atau nilai minimal pada pengeluaran yang diinginkan. Pemrosesan di infernsi menggunakan penilaian maksimal minimal.

\section{Defuzzifikasi}

Dimana proses penentuan rules atau grafik keanggotaan dalam penentuan pengeluaran fuzzy yang diinginkan.

Table 3. Table Rules keanggotaan fuzzy logic.

\begin{tabular}{|c|}
\hline Rulas \\
\hline 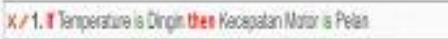 \\
\hline 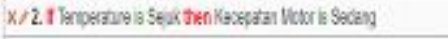 \\
\hline 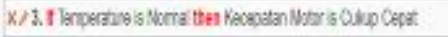 \\
\hline 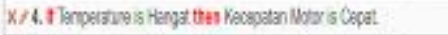 \\
\hline 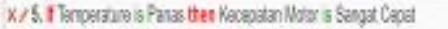 \\
\hline
\end{tabular}

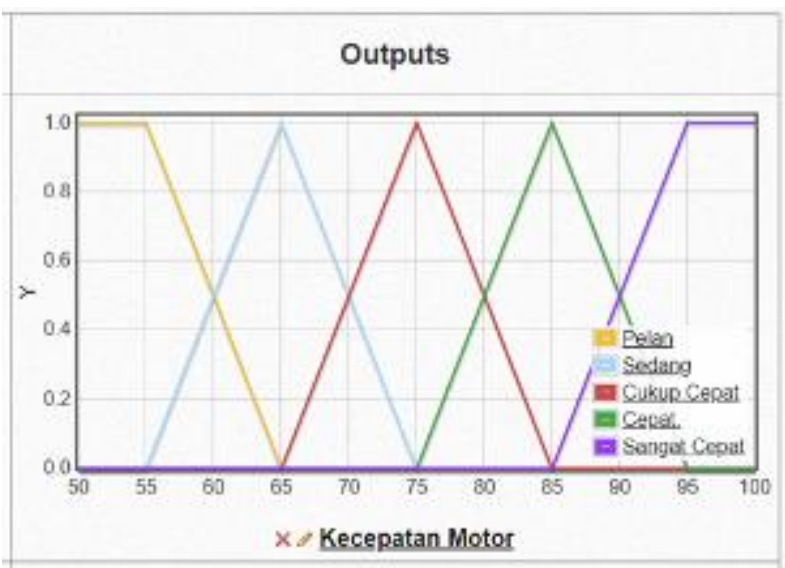

Gambar 13. Gambar grafik kecepatan motor.

\section{Teknik Pengumpulan dan Analisis Data}

Metode eksperimen dengan pengumpulan data primer dengan cara mengamati secara langsung tentang kegiatan yang berkaitan dengan tujuan penelitian untuk membandingkan dengan model 
pendingin yang serupa.

Teknik analisa data dengan membandingkan hasil dari tanpa menggunakna pendingin, menggunakan pendingin heatsink dan dan menggunakan system pendingin menggunakan air untuk menjaga atau menurunkan suhu panel surya supaya bisa bertahan lebih lama dalam penggunaan pada daerah tropis.

Tabel 2. data sheet panel yang digunakan.

\begin{tabular}{|l|l|}
\hline \multicolumn{2}{|c|}{ DATA SHEET } \\
\hline Rated maximum power (Pmix) & $20 \mathrm{~W}$ \\
\hline Voltage at Pmax (Vma) & $17.40 \mathrm{~V}$ \\
\hline Current Pmax (Imp) & $1.15 \mathrm{~A}$ \\
\hline Open - circuit voltage (Voc) & $22.40 \mathrm{~V}$ \\
\hline Short - circuit curreat (Isc) & $1.23 \mathrm{~A}$ \\
\hline Maximum system voltage & $700 \mathrm{VDC}$ \\
\hline Cell technology & Poly-Si \\
\hline Weight & $1.8 \mathrm{Kg}$ \\
\hline
\end{tabular}

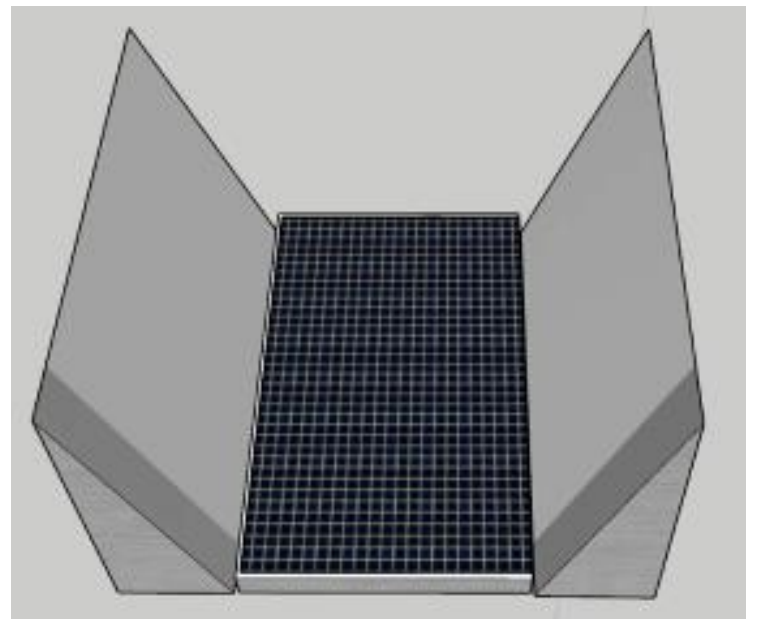

Gambar 14. Perancangan Panel surya dengan kaca di kiri dan kanan.

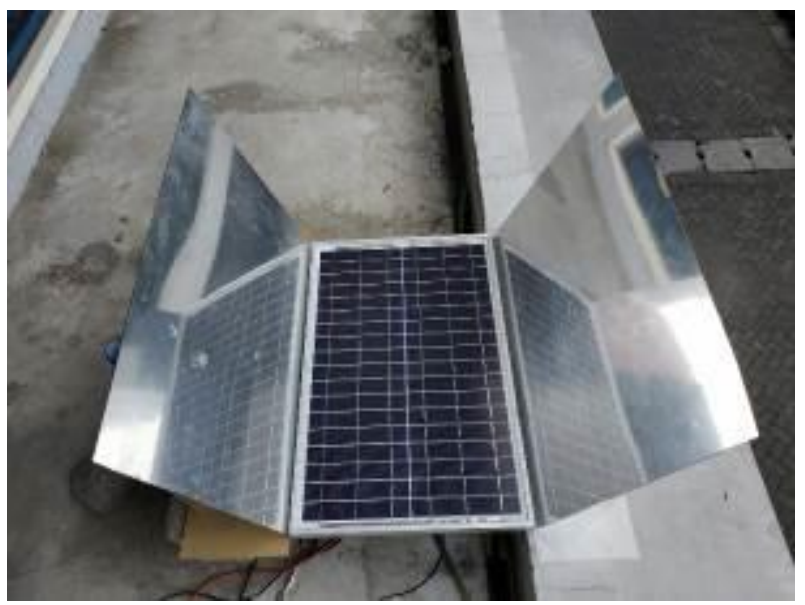

Gambar 15. Panel Surya dengan kaca di kiri dan kanan.

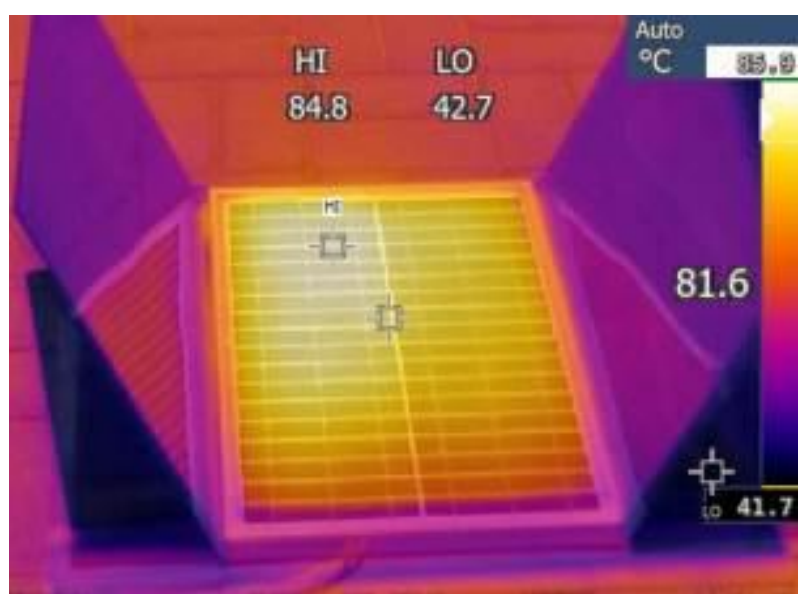

Gambar 16. Gambar yang di ambil dari thermal vision.

\section{HASIL DAN PEMBAHASAN}

Dalam menjaga suhu panel surya agar tetap kostan dan menghasilkan listrik yang baik dengan menggunakan air sebagai pendigin, memerlukan sebuah control untuk mengatur jalannya pendingin agar dapat bekerja dengan baik. Adapun hasil percobaan dapat digunakan sebagai pembanding dengan semua data yang diambil selama 5 (lima) hari berturut-turut.

Pembahasan dimulai dari percobaan panel surya dengan tidak menggunakan pendingin atau penurunan suhu untuk panel surya.

Tabel 3. Tanpa pendingin

\begin{tabular}{|c|r|r|r|r|c|}
\hline Hari & \multicolumn{1}{c|}{ Time } & \multicolumn{1}{c|}{ Tegangan } & \multicolumn{1}{c|}{ Arus } & \multicolumn{1}{c|}{ Daya } & Suhu Panel ${ }^{\circ} \mathrm{C}$ \\
\hline 1 & $9: 37: 10 \mathrm{AM}$ & 11,0951147 & 1,09938 & 11,586212 & 70,1 \\
\hline 2 & $9: 43: 50 \mathrm{AM}$ & 5,347223 & 0,476116 & 4,033628 & 69,7 \\
\hline 3 & $11: 45: 31 \mathrm{AM}$ & 4,463223 & 0,187244 & 0,85988 & 82 \\
\hline 4 & $10: 04: 14 \mathrm{AM}$ & 2,682341 & 0,179967 & 0,50158 & 73,5 \\
\hline 5 & $9: 11: 48 \mathrm{AM}$ & 1,422426 & 1,012202 & 1,44382 & 69 \\
\hline
\end{tabular}

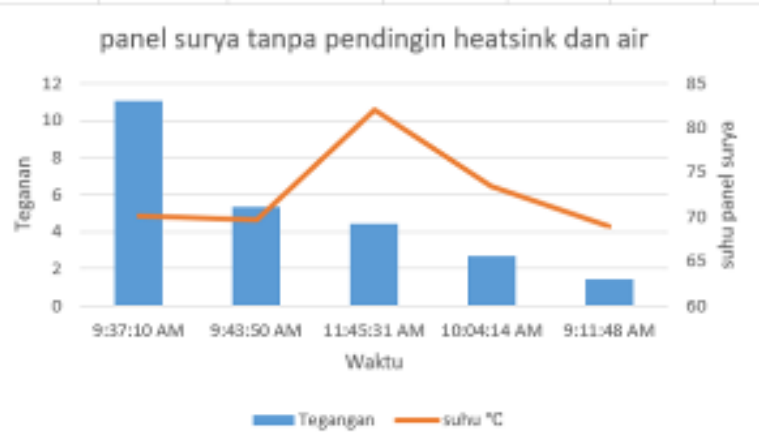

Gambar 17. Grafik Sensor Suhu dan Tegangan dari hasil panel tampa pendingin. 


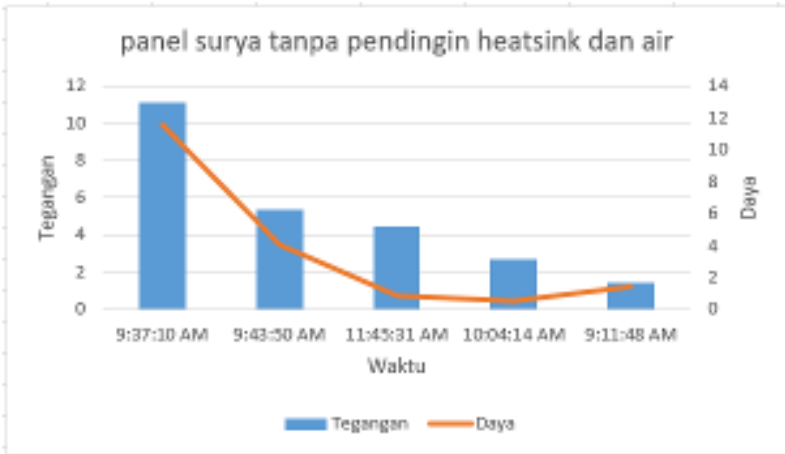

Gambar 18. Grafik Tegangan dan Daya dari hasil panel surya tanpa pendingin.

Gambar 17 dan gambar 18 merupakan grafik pada panel surya yang belum menggunakan pendingin. Gambar 13 menunjukkan penurunan penyerapan panel surya tepatnya pada pukul 11.45 am panel memiliki tegangan $4 \mathrm{~V}$ dengan suhu $82^{\circ} \mathrm{C}$. Gambar 18 menunjukkan penurunan daya yang dihasilkan pada hari penelitian dilakukan dimana pada pukul $11.45 \mathrm{am}$ terjadi penurunan daya terhadap tegangan dari $11 \mathrm{~V}$ menjadi $1 \mathrm{~V}$ dan dapat dikatakan hal ini disebabkan oleh peningkatan suhu dalam lima hari yang juga di pengaruhi oleh keadaan alam sekitar.

Tabel 4. Panel surya dengan heatsink

\begin{tabular}{|c|c|c|c|c|c|c|}
\hline Hari & Time & Tegangan & Arus & Daya & Suhu Panel ${ }^{\circ} \mathrm{C}$ & Suhu Heatsing ${ }^{\circ} \mathrm{C}$ \\
\hline 1 & $9: 24: 35 \mathrm{AM}$ & 7,36887 & 0,212023 & 1,631667 & 33,78664 & 30,064936 \\
\hline 2 & $9: 43: 50 \mathrm{AM}$ & 5,347223 & 0,746116 & 4,033628 & 32,43969 & 30,81393 \\
\hline 3 & $10: 00: 39 \mathrm{AM}$ & 5,173444 & 0,231327 & 1,348314 & 32,83046 & 28,48739 \\
\hline 4 & $10: 15: 14 \mathrm{AM}$ & 3,561771 & 0,278707 & 1,055709 & 32,48919 & 27,688263 \\
\hline 5 & $9: 11: 48 \mathrm{AM}$ & 1,422426 & 1,012202 & 1,44382 & 34,16754 & 32,1376361 \\
\hline
\end{tabular}

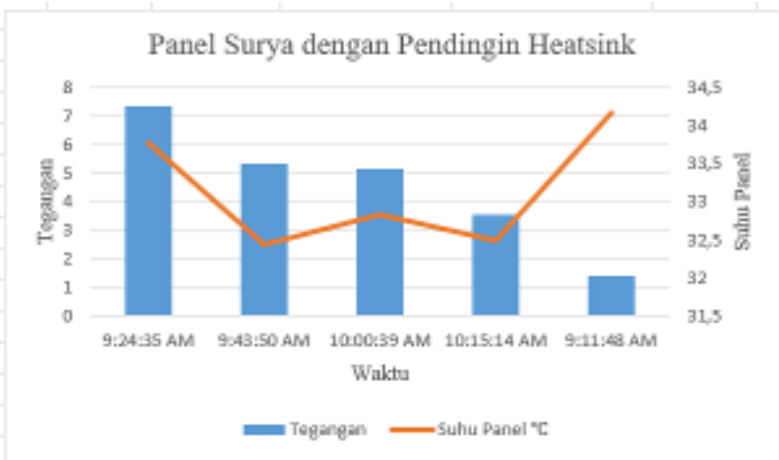

Gambar 19. Grafik Tegangan, Suhu Panel dan Waktu saat menggunakan pedingin heatsink.

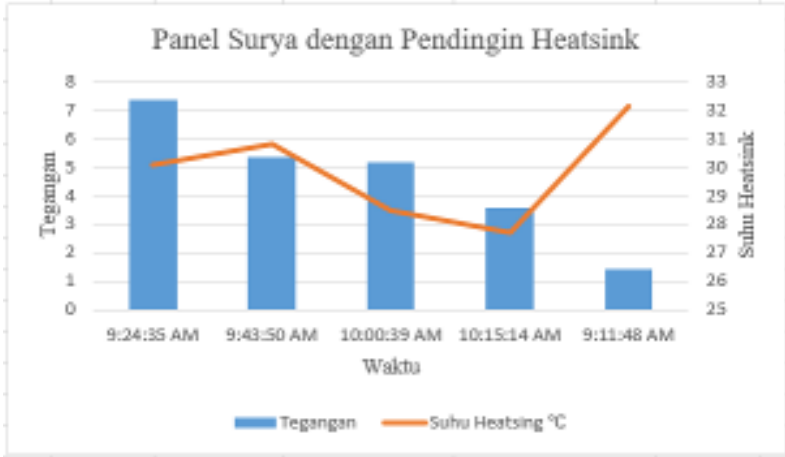

Gambar 20. Grafik Tegangan, Suhu Heatsink dan Waktu saat menggunakan pedingin heatsink.

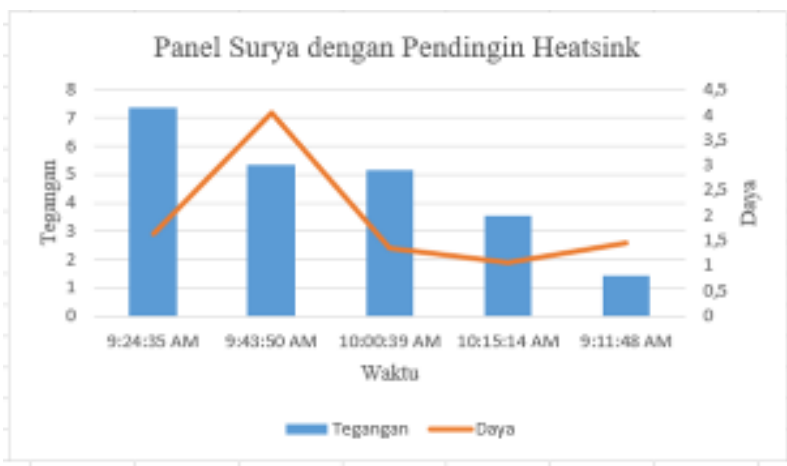

Gambar 21. Tegangan, Daya dan Waktu pada panel surya menggunakan pendingin Heatsink.

Gambar 19, merupakan hasil dari panel surya dengan tegangan $7.3 \mathrm{~V}$ dan $33.75^{\circ} \mathrm{C}$ suhu panel surya pada pukul 9.24 am. Pada gambar 20 suhu $30^{\circ} \mathrm{C}$ pada waktu yang sama dengan tegangan $7.3 \mathrm{~V}$ dan gambar 21 menunjukkan nilai rata - rata dan merupakan hasil dari penambahan heatsing pada panel surya. Dimana tegangan $5.5 \mathrm{~V}$ dan daya $4.1 \mathrm{~W}$ menunjukkan nilai yang mengalami perubahan secara signifikan, walaupun sudah ada proses pendingian yang dibantu dengan heatsing. Penurunan penyerapan ini masih terjadi dikarenakan oleh pengaruh alam sekitar.

Tabel 5. Panel surya dengan pendingin heatsink dan air

\begin{tabular}{|c|c|c|c|c|c|}
\hline Hari & Time & Tegangan & Daya & Suhu Panel ${ }^{\circ} \mathrm{C}$ & Suhu Heatsink ${ }^{\circ} \mathrm{C}$ \\
\hline 1 & $12: 14: 57$ PM & 17,76202 & 1,30749 & 28,43575 & 29,07337 \\
\hline 2 & $12: 15: 04$ PM & 11,98494 & 1,379206 & 28,44607 & 29,35908 \\
\hline 3 & $12: 15: 00$ PM & 17,34624 & 1,231523 & 28,15087 & 29,18496 \\
\hline 4 & $12: 15: 04$ PM & 18,31056 & 1,240604 & 27,37292 & 28,61085 \\
\hline 5 & $12: 14: 09$ PM & 14,13519 & 1,04279 & 27,15428 & 28,69579 \\
\hline
\end{tabular}




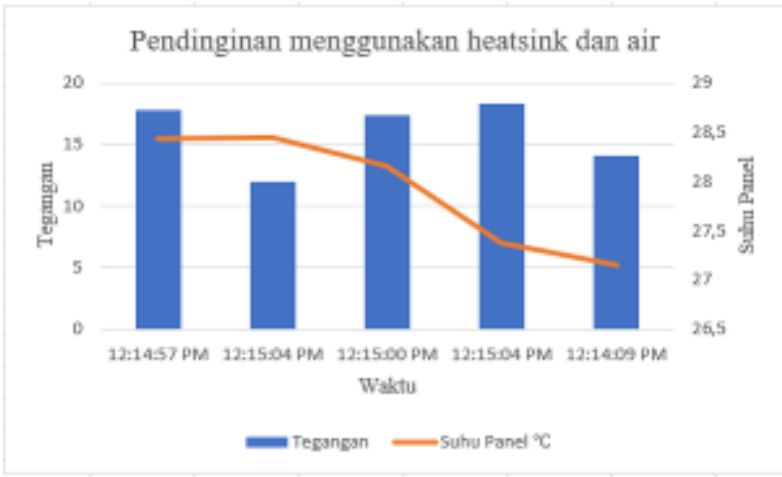

Gambar 22. Grafik pendinginan menggunakan heatsink dan air dengan nilai tegangan dan suhu pada panel surya.

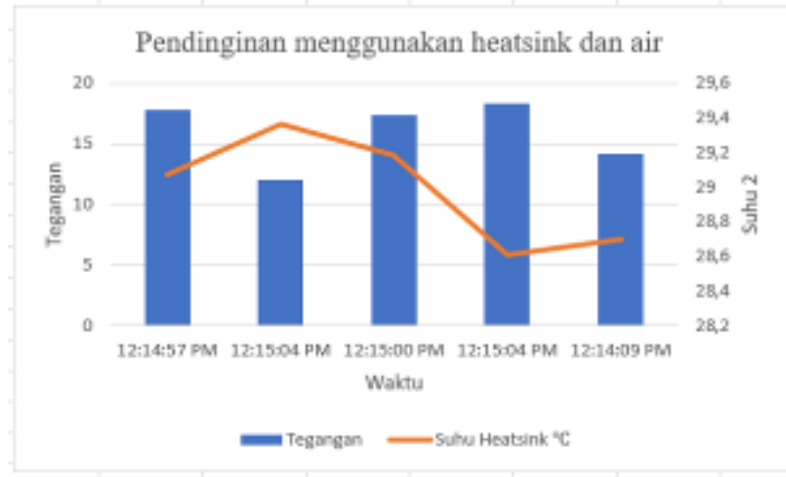

Gambar 23. Grafik pendinginan menggunakan heatsink dan air dengan nilai tegangan dan suhu pada heatsink dan air.

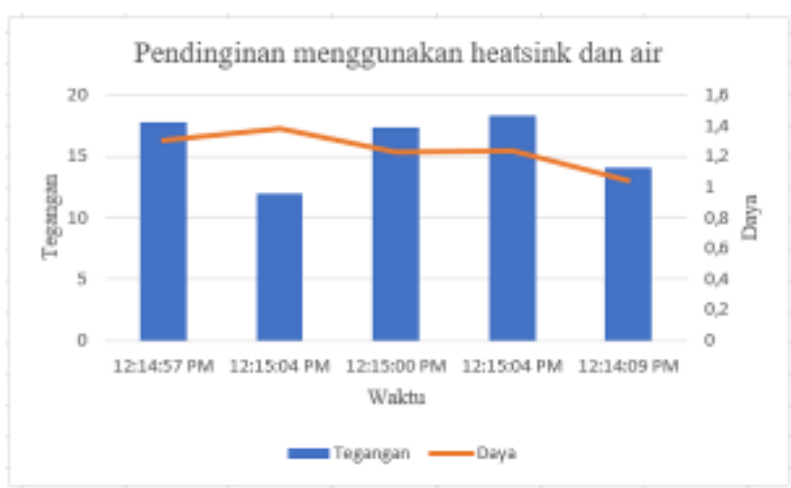

Gambar 24. Grafik pendinginan menggunakan heatsink dan air dengan nilai tegangan dan daya.

Gambar 22, merupakan hasil dari panel surya dengan tegangan $17 \mathrm{~V}$ pada $28^{\circ} \mathrm{C}$ suhu panel surya di pukul 12.14 pm. Gambar 23 menunjukkan pada waktu yang sama, suhu $27^{\circ} \mathrm{C}$ dengan tegangan 14V. Selanjutnya Gambar 24 menunjukkan nilai rata-rata dengan tegangan $16 \mathrm{~V}$ tehadap daya $8 \mathrm{~W}$ pada pukul $12.40 \mathrm{pm}$. Angka dari grafik pada setiap gambar menunjukan tingkat suhu dari panel, heatsing yang dialirkan air dan daya. Dalam hal ini dapat dikatakan bahwa dengan menjaga suhu pada panel surya dapat meningkatkan penyerapan daya.

\section{KESIMPULAN}

- Sistem pendingin untuk panel surya cocok di daerah tropis, karena sinar matahari sangat berlimpah dan terlebih lagi di area jalur khatulistiwa.

- Penggunaan fuzzy logic control dapat mengatur kecepatan air untuk pendinginan pada panel.

- Dengan menggunakan air, akan memperlambat kerusakan pada panel surya yang ada pada suhu yang tinggi.

- Air untuk pendinginan panel surya dapat di ambil dari air laut dan dapat dikembalikan ke laut lagi.

- PLTS dapat di terapkan pada kepulauan dengan kategori dari kecil ke sedang untuk membantu PLTD.

\section{UCAPAN TERIMA KASIH}

Ucapan terima kasih disampaikan kepada Politeknik Elektro Negeri Surabaya, Laboratorium Energi terbaharukan dan semua pihak yang telah membantu dan memberikan kontribusi demi kelancaran penelitian ini.

\section{DAFTAR PUSTAKA}

[1] Adhi Warsito, E. A. M. Y. N. O. a. B. W., 2013. Dipo PV Cooling, Penggunaan Sistem Pendingin Temperatur Heatsink Fan Pada Panel Sel Surya (Photovoltaic) Sebagai Peningkatan Kerja Energi Listrik Baru Terbarukan. Transient, 2(3), pp. 501-503.

[2] Amit Sahay, V. S. A. T. M. P., 2015. A Review Of Solar Photovoltaic Panel Cooling System With Special Reference to Ground Coupled Central Panel Cooling System (GC-CPCS). Elsevier, Volume 42, pp. 306-312.

[3] Chow, T., 2010. A Review on Photovoltaic/Thermal Hybrid Solar Technology. Elsevier, 87(Applied Energy), pp. 365-379.

[4] Colt, G., 2016. Performance Evaluation of a PV Panel By Rear Surface Water Active Cooling. International Conference on Applied and Theoretical Electricity (ICATE), pp. 1-5. 
[5] Cui Yong, W. Y. Z. L., 2015. Performance Analysis no A Building-Integrated Solar Heating and Cooling Panel. 74(Renewable Energy), pp. 627-632.

[6] Gumilar, A., 2011. Sistem air pendingin. jakarta: STE.

[7] Gur Mittelman, A. K. A. D., 2017. Solar Cooling With Concentrating Photovoltaic/Thermal (CPVT) System. Elsevier, Volume 48, pp. 2481-2490.

[8] Haitham M. Bahaidarah, B. T. P. G. a. S. R., 2015. A Combined Optical, Thermal and Electrical Performance Study of a V-Trough PV System-Experimental and Analytical Investigations. Energies.

[9] I.K. Karathanassis, E. P. V. B. G. B., 2017. Desain and Experimental Evaluation of a Parabolic-Trough Concentrating Photovoltaic/Thermal (CPVT) System With High-Efficiency Cooling. Elsevier, Volume 101, pp. 467-483.

[10] J.P. Holman, E. J., 1994. Perpindahan Kalor. Mahasiswa ed. Jakarta: Erlangga.

[11] kadir, A., 1995. Energi Sumber Daya, Inovasi, Tenaga Listrik Dan Potensi Ekonomi. II ed. Jakarta: Universitas Indonesia.

[12] Khwe, K. H., 2013. Pengaruh Temperatur Terhadapt Kapasitas Daya Panel Surya. ELKHA, 5(2), pp. 23-26.

[13] Kuswandi, S., 2007. Kendali Cerdas: teori dan aplikasi praktisnya. Surabaya: Andi.

[14] Matias, C. A., Santos, L. M., Alves, A. j. \& Calixto, W. P., 2016. Electrical Performance Evaluation of PV Panel Though Water cooling Technique. 2016 IEEE 16th International Conference on Environment and Electrical Engineering (EEEIC), pp. 15.

[15] Mingke Hu, B. Z. J. L. Y. W. G. P., 2017. Preliminary Thermal analisis of a comboned photovoltaic-photothermic-nocturnal radiative cooling system. Elsevier, XXX(Energy), pp. 1-12.
[16] Mulyono, 2010. Analisa Beban Kalor Menara Pendingin Basah Induced-Draft Aliran Lawan Arah. Semarang: Jurusan Teknik Mesin Politeknik Negeri Semarang.

[17] P G Nikhil, M. P., 2012. Performance Enhancement Of Solar Module by Cooling: An Experimental Investigation. Energy and Environment, 3(1), pp. 73-82.

[18] Putra, R. S., 2015. Analisa perhitungan beban cooling tower pada fluida di mesin injeksi plastik. Jurnal Teknik Mesin Mercu Buana, Volume 4, pp. 56-62.

[19] Rachman, T., 2011. PLN Manado Kembangkan Listrik Tenaga Surya di 14 Pulau.[Online] Available at: http://www.republika.co.id/berita/regional/n usantara/11/04/16/ljqpl6-pln-manadokembangkan-listrik-tenaga-surya-di-14pulau [Accessed 16 July 2017].

[20] Roepandi, O., 2008. Pengoperasian Sistem Air Pendingin. Surabaya: PT. Indonesia Power.

[21] Subandi, S. H., 2014. Korelasi Suhu dan Intensitas Cahaya Terhadap Daya Pada Solar Panel. Yogyakarta, Seminar Nasional Aplikasi Sains dan Teknologi (SNAST).

[22] Syafaruddin, S. M. S. F. M. R. A. S. L., 2017. Aplication Of Photovoltaic Power For Cooling System. Istambul, Internasioanal Conference On Energy and Therml Enginerring.

[23] Terano, T. K. A. d. M. S., 1987. Fuzzy Systems Theory and Its Applications. San Diego: CA: Academic Press, Inc.

[24] Yong Cui, Y. W. Q. H. S. W., 2016. Effect of Radiation and Convection Heat Transfer on Cooling Performance of Radiative Panel. Renewable Energy, Volume 99, pp. 10-17. 